Gönderilme Tarihi: 9 Eylül 2016

Kabul Tarihi: 8 Kasım 2016

\title{
İNSAN HAKLARININ BİRLEŞMİŞ MİLLETLER'İN KURUMSAL YAPISI İÇİNDE KORUNMASI
}

\section{Deniz KIZILSÜMER ÖZER*}

\author{
öz
}

Bu çalışmada Birleşmiş Milletler'in (BM) kurumsal yapısı içinde insan haklarının geliştirilmesi ve korunmasına yönelik çalışmalar ele alınıp değerlendirilmektedir. BM'nin küresel barışın ve güvenliğin sağlaması amacına hizmet edecek en önemli aracı insan haklarının geliştirilmesi ve korunmasıdır. Çalışmada ilk önce asli organların, daha sonra İnsan Hakları Konseyi'nin, son olarak da diğer tali organların insan haklarının kodifikasyonu ve korunması faaliyetleri ele alınmıştır. Günümüzde BM bünyesinde insan haklarının kodifikasyonu önemli ölçüde yeterli görülse de, özellikle denetim mekanizmalarının oluşum ve işleyişine ilişkin eleştiriler devam etmektedir. BM artan ya da yeni ortaya çıkan insan hakları ihlalleri ile mücadele etmektedir. BM'yi bu mücadelesinde en fazla zorlayan hususlardan biri, çoğu kez hükümetler arası nitelik taşıyan asli ya da tali organların politize olmalarıdır.

Anahtar Sözcükler: Birleşmiş Milletler Örgütü ve Insan Hakları, Insan Hakları Konseyi, Özel Usuller, Evrensel Periyodik Gözden Geçirme Mekanizması, Şikayet Usulü, İnsan Hakları İçin Uluslararası Soruşturma

\section{PROTECTION OF HUMAN RIGHTS IN THE ORGANIZATIONAL STRUCTURE OF THE UNITED NATIONS}

\begin{abstract}
In this article, the promotion and protection of human rights in the organizational structure of the United Nations (UN) will be scrutinized and evaluated. UN's main tool to provide global peace and security is the promotion and protection of human rights. In this study, firstly the primary and than the secondary organs of the UN's codification and control mechanisms of human rights have been scrutinized. Currently, the codification of the human rights in the auspices of the UN is regarded to be adequate, however the critics about the organization and functioning of the control mechanisms still continue. The UN has been combatting with the accelarated and ongoing human rights violations. The main challenge for the work of the UN is the politization and complexity of intergovernmental primary and secondary organs.
\end{abstract}

Keywords: United Nations and Human Rights, Human Rights Council, Special Procedures, Universal Periodic Review, Complaint Procedure, International Factfinding (Inquiry) for Human Rights

\footnotetext{
* Dokuz Eylül Üniversitesi, İşletme Fakültesi, Uluslararası İlişsiler Bölümü, İzmir, E-posta: deniz.kizilsumer@deu.edu.tr
} 


\section{İnsan Haklarının BM'nin Kurumsal Yapısı İçinde Korunması}

\section{GİRİş}

Birleşmiş Milletler Şartı uluslararası ilişkilerin temel kurallarının, ilkelerinin yer aldığı en temel uluslararası metindir. Kanımızca, Şart'ın 103. maddesi ile getirilen Şart'ın hükümlerinin diğer andlaşmalarla çatışması halinde üstün olacağına ilişkin hükmün Şart'a uluslararası alanda anayasal bir statü verdiği dahi söylenebilir. Bu bakımdan temelde hukuki bir konu olmasına karşın günümüzde büyük ölçüde uluslararası nitelik kazanan insan haklarının korunması bakımından Birleşmiş Milletler'in yetkilerinin ve etkinliğinin incelenmesi önemlidir. Bu çalışmanın amacı, "Birleşmiş Milletler İnsan Hakları Hukuku" olarak ifade edilebilecek bir konunun ana hatları ile ele alınıp değerlendirilmesidir.

BM Şartı incelendiğinde, insan haklarına yapılan temel göndermeler dikkat çekse de Şart'ın temel amacı, uluslararası barış ve güvenliğin sağlanmasıdır. Bu çerçevede, Şart'ta insan haklarının korunması başı başına özel bir amaç olarak düzenlenmemiş; insan haklarının korunması daha çok uluslararası barış ve güvenliğin sağlanması temel amacının gerçekleşmesine hizmet edecek bir araç olarak Şart'ta yer almıştır. Özellikle, Şart'a insan haklarına ilişkin hükümlerin alınması, dönemin ABD başkanının eşi ve önemli insan hakları aktivistlerinden Eleanor Roosevelt'in katkıları ile gerçekleşmiştir (Banketas ve Oette, 2013: 146147; Stewart, 2008: 90-93).

İnsan haklarının evrensel düzeyde korunmasına ilişkin temel hüküm olan Şart'ın 1(3) maddesinde, Örgüt'ün amaçlarından biri olarak "...ırk, cinsiyet, dil ya da din bakımından herhangi bir ayıım yapmaksızın temel özgürlükler ve insan haklarına saygının geliştirilmesi ve cesaretlendirilmesi için uluslararası iş birliği..." düzenlenmiş̧ir. Bunun dışında, Şart'ın 55. ve 56. maddelerinde insan haklarının korunmasına ilişkin genel hükümler vardır. Bununla beraber, Şart'ta üye devletler bakımından insan haklarının korunmasına yönelik yükümlülüklerin uygulanmasının sağlanmasını amaçlayan bir denetim mekanizması oluşturulmamıştır.

Şart'ta yer alan insan haklarına ilişkin hükümlerin genel ifadelerle kaleme alınması, Birleşmiş Milletler insan hakları hukukunun gelişimini önemli ölçüde etkilemiştir. BM asli organlarının insan haklarının korunmasına yönelik yetkileri diğer alandaki yetkilerinin yanında tedricen gelişmiş; asli organlar yanında BM bünyesinde insan haklarının korunmasına yönelik tali organlar ve denetim mekanizmaları oluşturulmuştur. Çalışmada öncelikle BM asli organlarının insan haklarının korunmasına yönelik işlevleri ve uygulamalar, daha sonra BM bünyesinde 


\section{Deniz Kızılsümer Özer}

insan hakları kurallarının geliştirilmesi ve bu kuralların uygulanmasına yönelik tali organ ve mekanizmalar ele alınarak değerlendirilecektir.

Özellikle BM Şartı'nın 2(7) maddesinde yer alan "Örgüt'ün devletlerin ulusal yetki alanına giren konulara müdahale edemeyeceği" ilkesi ile insan haklarının korunması arasındaki ilişki ele alınmalıdır. Uluslararası toplumun insan haklarının korunmasına ilişkin müdahaleleri çoğu zaman ulusal yetki alanına müdahale olarak görülmektedir. İnsan hakları ihlallerine sebep olan ya da bu ihlalleri önleyemeyen hükümetler insan hakları ihlalleri gerekçe gösterilerek iç işlerine müdahale edildiğini sıklıkla dile getirmektedirler. Esasen bunda kısmi bir haklılıkları da olabilmektedir.

Hemen belirtelim ki, devletler yalnızca Şart'a taraf olarak, insan hakları konularını tamamen yetki alanlarından çıkartmamış; ancak Şart'a taraf olarak devletler günümüzde insan haklarını koruma ve gerçekleştirme konusunda uluslararası alanda yükümlülük altına girmişlerdir. Günümüzde, insan hakları temel andlaşmalarında ya da örf ve âdet kuralı olarak kabul edilen insan haklarının ağır ihlalleri iç işlerinden sayılmamaktadır.

BM İnsan Hakları Hukuku denildiğinde özellikle 56. maddede yer alan, "üye devletlerin insan haklarının geliştirilmesi için Örgüt’le iş birliği yapmaları" hükmü çerçevesinde BM'nin temel hakların tanınmasına ve kodifiye edilmesine ilişkin çalışmaları ve insan haklarının korunması konusunda çalışan organlar akla gelir. Çalışmada özellikle organlar esas alınarak bir analiz yapılmakla birlikte BM'nin temel hakların kodifikasyonu yönündeki çabaları da gözden kaçırılmamalıdır.

Temel hakların sözleşmelerde yer alması, devletlerin bunlara uygun davranıp davranmadığının Birleşmiş Milletler tarafından denetlenmesi için yeterli değildir. Devletlerin insan hakları sözleşmelerinden doğan yükümlülüklerinin ihlali halinde bunlara uygunluğun sağlanması için bazı mekanizmaların oluşturulması gerekir. Günümüzde yeni hakların oluşturulmasından ziyade sözleşme hükmü, örf ve âdet kuralı, hukukun genel ilkesi ya da jus cogens kuralı olarak kabul edilen insan haklarına uygunluğun sağlanması önem kazanmıştır. Bu çerçevede insan haklarının uluslararası düzeyde korunmasında en önemli rol Birleşmiş Milletlerin asli ve tali organlarına düşmektedir; bu organlar hem kuralların oluşturulması hem de bu kuralların uygulanmasının sağlanması için çaba göstermektedirler (Buergenthal, 2006: 791).

Birleşmiş Milletler bünyesinde insan hakları normlarına uygunluğun sağlanmasına ilişkin kurumsal yapı iki ayrı düzeyde incelenecektir. 


\section{İnsan Haklarının BM'nin Kurumsal Yapısı İçinde Korunması}

Bunların ilki, BM'nin asli organlarınca gerçekleştirilen koruma, diğeri ise BM'nin tali organları tarafından gerçekleştirilen korumadır.

\section{İNSAN HAKLARININ BİRLEŞMİŞ MİLLETLER ASLİ ORGANLARI TARAFINDAN KORUNMASI}

Birleşmiş Milletler'in altı asli organı, Genel Kurul, Güvenlik Konseyi, Sekreterya, Uluslararası Adalet Divanı, Ekonomik ve Sosyal Konsey ve Vesayet Konseyi gerek Şart'ta açıkça düzenlenmiş gerekse uygulamadan doğan görev ve yetkileri çerçevesinde insan haklarının geliştirilmesi yönünde faaliyet göstermektedir.

\section{Genel Kurul}

BM Şartı'nın 13. maddesinde Genel Kurul'un "uluslararası iş birliğini geliştirmek ve uluslararası hukukun tedricen gelişmesini teşvik etmek" temel görevinden hemen sonra "...ırk, dil veya din farkı gözetmeksizin herkesin insan haklarından ve temel hürriyetlerinden faydalanmasını kolaylaştırmak için araştırmalar yapar ve tavsiyelerde bulunur." hükmü yer almaktadır. Esasen, Genel Kurul'un insan haklarının gelişmesine ve uygulanmasına yaptığı katkının kaynağı bu hükümdür. Genel Kurul'da Üçüncü Komite (Sosyal, İnsani ve Kültürel İşler Komitesi ${ }^{1}$ ) insan haklarının geliştirilmesi yönünde faaliyet göstermektedir. Üçüncü Komite aşağıda ele alınacağı üzere BM diğer organları ile İnsan Hakları Konseyi arasındaki eşgüdümü sağlar; tematik ya da ülke düzeyinde gerçekleşen insan hakları ihlallerine ilişkin kararları görüşür; özel usuller neticesinde hazırlanan raporları inceler. ${ }^{2}$

Genel Kurul'un insan hakları ihlallerine ve devletlerin insan hakları ihlallerini durdurmalarına yönelik ilk kararları hafif ya da zayıf olarak nitelenirken daha sonraki kararlarının talepkar ve kesin bir dille yazıldığı gözlenmektedir. Hatta apartheidın sona ermesine yönelik bazı kararlarında Genel Kurul üye devletleri ihlale yol açan devletlere müeyyide uygulamaya davet etmiştir. ${ }^{3}$ Elbette ki, Genel Kurul kararlarının üye devletler bakımından bağlayıcı olmaması Genel Kurul'un özellikle geniş kapsamlı insan hakları ihlalleri ile mücadele gücünü azaltmıştır (Buergental, 2006: 790).

Genel Kurul'un kararları ve bildirileri üye devletler bakımından bağlayıcı kabul edilmemekle beraber, insan haklarına ilişkin bildirilerin

${ }^{1}$ Social, Humanitarian, Cultural Affairs Committee.

2 Third Committee, http://www.un.org/en/ga/third/

3 UNGA Res 1761 (1962) 


\section{Deniz Kızılsümer Özer}

insan haklarının gelişmesine önemli etkileri olmuştur. Genel Kurul tarafından insan haklarının korunması amacına yönelik birçok bildiri ve karar kabul edilmiştir. Bu bildiriler arasında önemi itibariyle 10 Aralık 1948 tarihli İnsan Hakları Evrensel Bildirisi (İHEB) üzerinde durulmalıdır. Bildirinin önemi sebebiyle kabul tarihi olan 10 Aralık "Dünya İnsan Hakları Günü" olarak kutlanmaktadır. İHEB, BM Genel Kurulu'nda, 48 devletin olumlu, sekiz devletin çekimser oyu ile kabul edilmiştir. Bildiri'nin kabulü için Genel Kurul'da yapılan oylamada Suudi Arabistan evlenme hakkına, Güney Afrika ırk eşitliğine itiraz ederek; Sovyetler Birliği, Bildiri'de devletin egemenliğine, ekonomik ve sosyal haklara yer verilmemesine itiraz ederek çekimser oy kullandılar. Bildiri'ye karşı olumsuz oy kullanan devlet bulunmamaktadır (Haas, 2008: 81).

Tekrar belirtilmesi gerekir ki, İHEB, BM Genel Kurulu'nun bir kararı olması bakımından üye devletler bakımından hukuki bağlayıcılığı bulunmamaktadır. Bununla beraber, Bildiri'nin bazı hükümlerinin örf ve âdet kuralı ya da hukukun genel ilkesi niteliğinde olması sebebiyle bağlayıcılık kazandığı ileri sürülmektedir. Keza ileride ele alacağımız BM bünyesinde yapılan insan hakları sözleşmelerinde yer alan bazı hakların da örf ve âdet hukuku kuralı haline geldiği belirtilmektedir (Buergenthal, 2006: 790). Bildiri'de temel olarak insan haklarının evrenselliği, insanların insan onuruna sahip olması sebebiyle eşitliği ilkesi yer almaktadır. İHEB, 30 maddeden oluşmaktadır. Bildiri'de kişisel ve siyasal hakların yanında ekonomik, sosyal ve kültürel haklar da listelenmiştir. İlk iki maddede insan haklarının herkes tarafından doğumla kazanıldığı, seçilmiş azınlıklar için ayrıcalık olmadığı belirtilmekte, mahrum edilecek ya da bağışlanacak ayrıcalıklar olmadığı garanti edilmektedir (Shaw 2008: 278). Bildiri'de yer alan hakların daha sonraki tarihlerde yapılan pek çok anayasaya, insan hakları sözleşmelerine alınması yoluyla bağlayıcılık kazanması Bildiri'nin öneminin bir göstergesidir. İnsan Hakları Evrensel Bildirisi kabulünden sonra yapılan seksen civarında uluslararası sözleşmenin ve bildirinin hazırlanmasına öncülük etmiştir (Shaw, 2008: 278-279; Stewart, 2008: $89 \mathrm{vd}$.).

Genel Kurul'un insan haklarının korunmasına yönelik diğer normatif çabaları ise özellikle temel insan hakları sözleşmelerinin kabulüne yöneliktir. İnsan Hakları Komisyonu tarafından metinleri hazırlanan insan hakları sözleşmeleri Genel Kurul'da kabul edildikten sonra devletlerin imza ve onayına açılmaktadır.

Genel Kurul, ayrıca, küresel düzeyde insan hakları konferanslarının düzenlenmesine ön ayak olmuştur. Bu çerçevede, 2001 tarihli "Birleşmiş Milletler Irkçlığa, Irkçı Ayrımclığa, Yabancı Düşmanlığına ve Diğer İlgili 


\section{İnsan Haklarının BM'nin Kurumsal Yapısı İçinde Korunması}

Hoşgörüsüzlüklere Karşı BM Dünya Konferansı", ayrıca 2009'da Cenevre'de "Durban Gözden Geçirme Konferansı", "2005 Dünya Zirvesi", "2012 Hukuk Devleti Yüksek Düzey Toplantısı" önemlidir (Connors ve Schmidt, 2014: 392). Genel Kurul tarafından alınan önemli kararlar arasında, 1956 tarihli soykırımın uluslararası suç olduğuna ilişkin karar ve Nuremberg ilkeleri sayılabilir. İlk önce, Genel Kurul bildirisinde ele alınan bir konunun daha sonra andlaşma haline getirildiği de görülmektedir. Bu sayede, insan hakları hukukunun tedricen gelişmesi sağlanmaktadır. Bunun en bilinen örneği, 1959 Çocuk Hakları Bildirisinde yer alan birçok ilke ve kuralın 1989 tarihinde yapılan "Çocuk Hakları Sözleşmesi" ile bağlayıcılık kazanmasıdır (Mertus, 2005: 39). Bütün bu sözleşme ve bildiriler, bazı insan haklarının örf ve âdet kuralı, hukukun genel ilkesi hatta jus cogens haline gelmesini sağlamıştır.

$\mathrm{Bu}$ çerçevede, yukarıda da belirttiğimiz üzere Genel Kurul'un özellikle Güney Afrika'daki apartheid rejiminin ve İsrail'in sebep olduğu insan hakları ihlallerinin kınanmasına ilişkin onlarca kararı ${ }^{4}$ önemlidir. Genel Kurul'un Güney Afrika ve İsrail'e yönelik kararları ve bildirileri sayesinde uluslararası toplumun konuya ilişkin hassasiyeti artmıştır. Daha yakın tarihlerde ise 2013 yılında Genel Kurul "Afrika'daki Çatışmaların Barışçı Çözümüne İlişkin Siyasi Bildiri"yi yayınlamıştır. Ayrıca, Genel Kurul tarafından kabul edilen 2010 tarihli "İnsan Ticareti ile Mücadele Hareketi Küresel Planı" dikkat çekicidir.

Ayrıca, insan hakları sözleşmelerinin uygulanmasını sağlamak üzere oluşturulan organlar (Komiteler) ve Ekonomik ve Sosyal Konsey insan haklarına ilişkin raporlarını Genel Kurul'a sunmaktadırlar (Connors ve Schmidt, 2014: 392). Genel Kurul, bu çerçevede dikkatini çeken insan hakları ihlalleri konularda inceleme yapmak için raportör atayabilir. Bu çerçevede, devletler de dikkat çekilmesini istedikleri insan hakları konularını Genel Kurul'un önüne getirebilirler. Günümüzde, Genel Kurul müzakerelerinin yaklaşık beşte birinin insan haklarının korunmasına ayrıldığı belirtilmektedir (Mertus, 2005: 40).

Bununla beraber, Genel Kurul, insan hakları konularından siyasi ağırlıkı kararlar alması, insan haklarının görüşüldüğü toplantılarda "blok oy kullanılması" ya da "bazı devletlerin ihlallerine göz yumulurken bazı devletlerin ihlallerinin üzerinde çok durulması" sebebiyle eleştirilmektedir (Mertus, 2005: 40-41). Son dönemlerde ise geçiş dönemindeki ülkelerde ve silahlı çatışmalar sonrasında yeni kurulan ve otoritesini kaybetmiş ülkelerde adaletin sağlanması, insan haklarının korunması ve hukukun

${ }^{4}$ Bkz. http://www.humanrightsvoices.org/EYEontheUN/priorities/actions/body/?u $=1 \& u l=1 \&$ un_s=0\&s=82\&ya $=1 \& \mathrm{tp}=1 \& \mathrm{tpn}=$ Resolution \& $\mathrm{rm}=1 \&$ search $=1$ 


\section{Deniz Kızılsümer Özer}

üstünlüğünün tesisi Genel Kurul'un ajandasında yer alan önemli konulardır (Banketas ve Oette, 2013: 169).

Son olarak, aşağıda ele alacağımı İnsan Hakları Konseyi'nin günümüzde Genel Kurula bağı olduğu da belirtilmelidir. 2006 yılından önce İnsan Hakları Komisyonu'nun ECOSOC bünyesinde olduğu düşünüldüğünde Konsey'in Genel Kurulun bünyesine alınması Genel Kurul'un ileride de insan hakları konusunda etkinliğini arttıracağını göstermektedir.

\section{Güvenlik Konseyi}

Öncelikle, Güvenlik Konseyi insan haklarının korunması amacıyla kurulmuş bir organ olmadığı belirtilmelidir. Güvenlik Konseyi, uluslararası barış ve güvenliğin korunması konusunda $B M^{\prime}$ nin en yetkili organı olmasına karşılık günümüzde mesaisinin önemli bir bölümünü insan haklarının korunmasına ayırmaktadır. Konsey'in insan haklarının korunmasına ilişkin olarak aldığı kararlar, genellikle çatışma bölgelerine ve yoğun insan hakları ihlallerinin yaşandığı olaylara ve yerlere ilişkindir. Konsey kararlarının üye devletler bakımından bağlayıcı olması ve Konsey'in diğer asli organlara nazaran daha hızlı kararlar alabilmesi, ağır insan hakları ihlallerine müdahale edebilmesini sağlamaktadır (Banketas ve Oette, 2013: 170).

Özellikle Güvenlik Konseyi'nin BM Şartı'nın VII. Bölümü çerçevesinde aldığı "müeyyidelere" ya da "barış gücü oluşturulmasına" ilişkin kararlarına baktığımızda, ağır insan hakları ihlallerinin gerçekleştiği ülkelere ilişkin oldukları görülmektedir. Konsey, ağır insan hakları ihlallerini uluslararası barış ve güvenliğe bir tehdit olarak görmektedir (Connors ve Schmidt, 2014: 392). Güvenlik Konseyi'nin insan haklarını ihlal eden rejimlere karşı aldığı bazı müeyyide kararları dikkat çekicidir. Özellikle Soğuk Savaş döneminde Güvenlik Konseyi'nin Güney Afrika Cumhuriyeti $^{5}$ ve Güney Rodezya ${ }^{6}$ için aldığı müeyyide kararları bu ülkelerdeki insan hakları ihlallerinin azalmasını; hatta uzun dönemde Güney Afrika Cumhuriyeti'nde apartheid rejiminin son bulmasını sağlamıştır (Cortrights ve Lopez, 2002: 94).

${ }^{5}$ South Africa, UNSC Res 417 (1977); UNSC Res 558 (1984).

${ }^{6}$ Güvenlik Konseyi'nce insan hakları ihlalleri de gerekçe gösterilerek ilk müeyyide kararı 1966 yılında Güney Rodezya'daki beyaz azınlık rejiminin 1965 yılında Tek Tarafıı Bağımsızlık kararı üzerine alınmıştır. Kararda bu bağımsızlık ilanının ve hukuk dışı rejim tarafından gerçekleştirilen işlemlerin Afrika halklarıın selfdeterminasyon hakkını ihlal etmesi sebebiyle hukuken yok hükmünde olduğu ve tanınmaması gerektiği belirtilmiştir. Bkz.:Southern Rodesia, UNSC Res 216 ve 217 (1965); UNSC Res 232 (1966); UNSC Res 277 (1970). 


\section{İnsan Haklarının BM'nin Kurumsal Yapısı İçinde Korunması}

Ayrıca, 1990'dan bu yana uygulanan müeyyide rejimlerinden $11^{\prime}$ inde insan haklarının korunması Güvenlik Konseyi'nin önceliklerden biri olarak sayılmışıı. Günümüzde uygulanmakta olan 16 müeyyide rejiminin sekizinde insan hakları ihlalleri müeyyide uygulanmasını gerektiren kriterlerden biri olarak sayılmışır.7

Bu çerçevede Güvenlik Konseyi'nin özellikle Darfur krizi sırasında aldığı kararda kullandığı ifadeler dikkat çekicidir. Kararda Konsey genellikle insan haklarının korunmasına yönelik ifadeler kullanmıştır. Dipnotta kararda yer alan ifadelerden bazı örnekler verilmesi yararlı görülmektedir. ${ }^{8}$

Bununla beraber, bazı olaylarda Güvenlik Konseyi'nin Şart'ın 41. Maddesi çerçevesinde aldığı müeyyide kararlarının insan hakları ihlallerine sebep olabileceği de yazarlar tarafından vurgulanmaktadır. Müeyyide kararları özellikle sivil halkı etkilediklerinde demokratik olmayan, insan haklarını ihlal eden hükümetleri cezalandırmaktan ziyade sivil halkın insan haklarını ihlal etmektedirler (Doxey, 1996: 93-94; Farrall, 2007: 6; Frowein, 2001: 129-131; Schmitz ve Sikkink, 2005: 530). Bu çerçevede, Güvenlik Konseyi kararlarının insan hakları ihlaline yol açması halinde gidilebilecek hukuki ya da yargısal bir yol bulunmadığı da belirtilmelidir (Arsava, 2007: 1). Müeyyidelerin sivil halkı etkilemesi, özellikle, ekonomik, ithalat ambargosu uygulanması yani halkın yaşamsal ilaçı

7 Bu kararlar; Fildişi Sahilleri, UNSC Res 1572 (2004), UNSC Res 1975 (2011), UNSC Res 2000 (2011), UNSC 1572 (2004); Darfur, UNSC Res 1591 (2005); Kongo Demokratik Cumhuriyeti; UNSC Res 1698 2006; Libya UNSC 1970 (2011); Somali ve Eritre, UNSC 2002 (2011); Orta Afrika Cumhuriyeti, UNSC Res 2134 (2014); Yemen UNSC Res 2014; Güney Sudan UNSC Res 2206 (2015). Bkz.: Special Research Report, Human Rights and Security Council- An Evolving Role, 25 January 2016.

8 Darfur için 1591 sayılı, 2005 tarihli karardan "Insan hakları ve insancl hukuk ihlallerinin sona erdirilmesi ve Darfur bölgesi dahil olmak üzere dokunulmazlıkların kalması için bütün gerekli tedbirlerin alınması..."

"...bütün Sudan da olduğu gibi özellikle de Darfur bölgesinde uzun süredir devam etmekte olan çatışmanın siviller için ağır sonuçları ve özellikle yerinden edilmiş ve sığınmacı sayısındaki artışın verdiği ağır endişe..."

"Barış sürecinin işlemesi için yerinden edilmiş ve sığınmacı durumunda olan kişilerin gönüllü ve sürdürülebilir olarak geri dönmeleri barış sürecinin yerleşmesi için önemli bir unsurdur."

"İnsani yardım çalışanlarının güvenliği, sığınmacı olan, yerinden edilen ve savaşın etkilediği insanlar dahil olmak üzere ihtiyacı olan insanlara ulaşmaları"

"8 April 2004 tarihli N'djamena Ateşkes Andlaşmasının ve 2004 Abuja Protolünün ihlali insani yardım çabalarına ağır zararlar vermektedir."

"Darfur'daki insan hakları ve insancl hukuk ihlalleri sivillere uygulanan şiddet ve kadın ve kızlara uygulanan cinsel şiddet... bu şiddetten sorunlu olanların belirlenmesi ve adaletin önüne getirilmesi..."

"...Darfur'da çatışmanın bütün taraflarının sivillere karşı şiddete son vermeleri..." 


\section{Deniz Kızılsümer Özer}

yiyecek ve suya ulaşamaması sebebiyle ortaya çıkmaktadır. Keza, kuvvet kullanımı kararı çıkması halinde çatışma dışı sivillerin kazara öldürülmesi, yaralanması ya da hastane, okul gibi yerlerin vurulması söz konusu olabilmektedir. Sivillerin haklarının ihlaline yol açan müeyyidelere verilen en temel örnek,1990'da Kuveyt'in işgal ve ilhakından sonra Irak'a uygulanan müeyyidelerdir. İnsani eleştiriler sonrasında Güvenlik Konseyi, 968 sayılı "Yiyecek için Petrol" (oil for food) kararı ${ }^{9}$ ile Irak'a petrol karşılığında yiyecek, ilaç ve insani madde alma izni vermiştir. Bununla beraber, Müeyyide Komitesi'nin çift kullanımı olabilecek malların ülkeye girişine izin vermemesi, alt yapı için yeterli fonlara ulaşılamaması, yolsuzluk ve kötü yönetim de eklenince "Yiyecek için Petrol" kararı da müeyyidelerin insan hakları ihlallerine yol açmasına son verememiştir (Banketas ve Oette, 2013:173; Charron, 2013: 179-180).

Bütün bu sebeplerle, son dönemde Güvenlik Konseyi müeyyidelerinin yöntem değiştirdiği görülmektedir. Bunun amacı, sivilleri müeyyidelerden etkilenmemesinin sağlanması ve müeyyidelerin bu yolla etkinliklerinin artırımasıdır. Esasen silahlı çatışma hukukunun en önemli ilkelerinden birisi sivillerin korunmasıdır. "Akıllı ya da hedefli müeyyideler" olarak adlandırılan müeyyideler ile belli etkinliğe sahip siyasetçilere ya da askeri, istihbarat görevi yapan kişilere, gruplara seyahat yasağı getirilmesi, bankadaki paralarının bloke edilmesi ve/veya bölgeye silah ambargosu getirilmesi yoluna gidilerek sivillerin müeyyidelerden en az şekilde etkilenmeleri amaçlanmaktadır ${ }^{10}$ (Forsythe, 2015: 198; Cortright ve Lopez, 2002: 93, 133; Connors ve Schmidt, 2014: 393).

Ayrıca, Güvenlik Konseyi barış gücüne, barışın tesisi için kurduğu misyonlara da insan haklarının geliştirilmesine ve korunmasına yönelik görevler vermektedir (Connors ve Schmidt, 2014: 393). Özellikle, bir misyona silahlı kuvvet kullanma izni verilmesi, misyonun sivillerin insan haklarının korunmasında önemli görevler üstlenmesini sağlayabilir. Bunun için verilen Somali örneği "insani kurtarma operasyonu" olarak adlandırımıştır. ${ }^{11}$ Ayrıca, 2010 yılı sonu 2011 yılı başında Fildişi Sahilleri'nde seçim sonrasında sivil halka karşı uygulanan şiddet, 1975 sayılı Güvenlik Konseyi kararı ile kınanmış ve UNOCI ${ }^{12}$ kurulmuştur. UNOCI, "mevcut fiziksel şiddet tehlikesine karşı sivillerin korunması için bütün gerekli araçların kullanması" konusunda yetkilendirilmiştir (Higgins,

\footnotetext{
9 UNSC Res 968 (1995).

${ }^{10}$ Ayrıca, bir örnek de Güvenlik Konseyi'nin 2011 yılında Libya için aldığı müeyyide kararıdır; SC Res 1970 (2011).

11 UNSC Res 1724 (2006).

12 United Nations Operation in Côte d'Ivoire, UNSC Res 1975 (2011) par.6.
} 


\section{İnsan Haklarının BM'nin Kurumsal Yapısı İçinde Korunması}

2016: 10). Günümüzde barış gücünün görevleri, birinci kuşak görevleri olarak nitelenen silah bırakma andlaşmalarının uygulanmasının ve askerden arındırılmış bölgelerin denetlenmesinden daha ileri bir düzeye gelmiştir. İkinci kuşak barış güçlerine geniş kapsamlı insan hakları ihlallerinin incelenmesine ve suçluların adalete teslimine ilişkin görevler de verilmektedir. Darfur'da 2007 yllında kurulan barış gücü buna iyi bir örneğidir. ${ }^{13}$

Son olarak, Eski Yugoslavya için Kurulan Uluslararası Ceza Mahkemesi ile Ruanda Uluslararası Ceza Mahkemesi'nin Güvenlik Konseyi kararları ile kurulmuş oldukları belirtilmelidir. ${ }^{14}$ Her iki mahkeme de aldıkları kararlar ile uluslararası ceza hukukunun gelişmesine katkıda bulunmuş ve daha sonra sürekli bir mahkeme olarak Uluslararası Ceza Divanı'nın (UCD) kurulmasına öncülük etmişlerdir. Hukuki kişiliğe sahip bir uluslararası örgüt olarak Roma Statüsü ${ }^{15}$ ile kurulan Divan, uluslararası suç olarak nitelenen savaş suçları, insanlığa karşı suç, soykırım ve saldırı suçlarını işleyen kişileri yargılama yetkisine sahiptir. Divan'ın yargılama yetkisini kullanması için BM Güvenlik Konseyi ya da Divan'ın Statüsüne taraf devletlerden biri, sayılan suçların soruşturulmasını başlatmak üzere UCD Savclığı'na başvurabilir. Ayrıca, Savcı propio motu soruşturma yapabilir. Savcı tarafından toplanan deliller ışığında UCD Genel Kurulu yargılama yetkisi olup olmadığı konusunda bir karar vermektedir ${ }^{16}$ (Connors ve Schmidt, 2014: 393; Martin vd., 2011: 8; Schabas, 2010). Günümüzde UCD'de görülmekte olan davalara bakıldığında 10 ayrı ülkede gerçekleşmiş uluslararası suçların yargılandığı görülmektedir. Bu ülkeler Uganda, Darfur (Sudan), Demokratik Kongo Cumhuriyeti, Merkezi Afrika Cumhuriyeti (iki ayrı dava), Libya, Kenya, Fildişi Sahilleri, Mali ve Gürcistan'dır. ${ }^{17}$ Divan'da görülmekte olan davalara bakıldığında Gürcistan hariç hepsinin Afrika'da işlenen suçlara ilişkin olduğu görülmektedir. Dünya'nın çeşitli yerlerinde de benzeri suçlar işlenmekte, bazılarına batılı devletlerin vatandaşlarının karışması da söz konusu olmaktadır. Büyük çoğunlukla Afrika ülkelerinde yaşanan suçların Divan'ın önüne gelmesi Divan'ın "Afrika Uluslararası Ceza Mahkemesi" gibi algılanmasına; bir

\footnotetext{
${ }^{13}$ African Union-United Nations Hybrid Operation in Darfur (UNAMID), UNSC Res 1769 (2007).

14 International Criminal Tribunal for the Former Yugoslavia, 25 Mayıs 1993, UNSC Res 827; International Criminal Tribunal For Ruanda, Kasım 1994, UNSC Res 1955.

15 Roma Statüsü'nün kabul tarihi, 17 Temmuz 1998; yürürlüğe giriş tarihi 2 Temmuz 2002.

16 Örneğin, Darfur olayları Savcının inisiyatifi ile UCD’nin önüne gelmiştir.

17 https://www.icc-cpi.int/get-involved/pages/academics-and-researchers.aspx.
} 


\section{Deniz Kızılsümer Özer}

mahkeme olarak Divan'a tarafsı olmama, politize olma eleştirilerinin yapılmasına sebep olabilir. Bu da Divan'ın saygınlığını ve içtihatlarının etkisini azaltabilir.

Güvenlik Konseyi, yalnızca insan hakları ihlalleri yapan devletlere karşı değil, aynı zamanda devlet olmayan aktörlere karşı, örneğin, Somalili deniz haydutlarına karşı kuvvet kullanılmasına ya da cezai yargılama yapılmasına ilişkin kararlar da almışıı ${ }^{18}$ (Banketas ve Oette, 2013: 172).

Güvenlik Konseyi tarafından Somali için 1992 tarihinde alınan 794 sayllı karar ise, "Somali'de insani kurtarma operasyonu için gerekli ortamın sağlanması amacıyla bütün gerekli araçların kullanılmasını" öngörmektedir (Mertus, 2005: 107). Bu karar ağır insan hakları ihlalleri karşısında askeri müdahaleye izin veren önemli bir karardır. Ancak, günümüzde Güvenlik Konseyi veto sebebiyle ağır insan hakları ihlallerine müdahale edemediği için eleştirilmektedir. Özellikle, Soğuk Savaş sonrasında ortaya çıkan, soykırım ya da katliamlarla sonuçlanan pek çok silahlı çatışmaya veto sebebiyle zamanında müdahale edilememiştir. Çin ve Rusya batılı güçlerin askeri kuvvetlerinin çatışmalı alanlara yerleşeceğini ya da askeri müdahalenin batılıların çıkarlarına hizmet edeceğini düşündüklerinde Güvenlik Konseyi'nde veto yetkilerini kullanmaktadırlar. Örneğin 2007 yılında Myanmar hakkında yapılan bir oylamada, Myanmar'ın insan hakları sicilinin kötü olmasına karşıılık durumun iç işlerine ilişkin olduğu ve uluslararası barış ve güvenliği etkilememesi sebebiyle Çin ve Rusya veto yetkilerini kullanmışlardır. Benzer bir durum, 2008 yılında Zimbabve'de Mugabe hükümetine ağır müeyyideler uygulanması Güvenlik Konseyi'nin önüne geldiğinde de söz konusu olmuştur. 90'lı yıllarda Balkanlar, Ruanda ve Somali'de gerçekleşen ağır insan hakları ihlallerine hatta soykırıma müdahale veto sebebiyle mümkün olmamıştır. Halen devam eden Suriye iç savaşına müdahale de veto sebebiyle mümkün olmamaktadır. Sonuç olarak, Güvenlik Konseyi'nde veto yetkisine sahip devletlerin insan haklarının korunmasına ilişkin yaklaşımlarının çok da tutarlı olmadığı görülmektedir (Forsythe, 2015: 190-191).

Ağır insan hakları ihlallerinin sona erdirilmesi amacıyla askeri müdahale kararı alınması ise günümüzde uluslararası hukukun en tartışmalı konularından biridir. Güvenlik Konseyi'nde veto sebebiyle 90'ı yıllarda soykırım ve etkin temizlik gerçekleşen yerlere dahi müdahale kararı alınamaması, 2000'li yıllarda koruma sorumluluğu fikrinin ortaya

18 İlk karar UNSC Res 1816 (2008), son karar UNSC Res 2020 (2011) olmak üzere, toplam 10 karar verilmiştir. 


\section{İnsan Haklarının BM'nin Kurumsal Yapısı İçinde Korunması}

çıkmasına neden olmuştur. Koruma sorumluluğu temel olarak iki belgede yer almaktadır. Bu belgeler, 2001 tarihli Müdahale ve Devletin Egemenliği Uluslararası Komisyonu'nun (ICISS) Koruma Sorumluluğu Raporu ve BM Genel Kurulu tarafından kabul edilen 2005 Dünya Zirvesi Sonuç belgesinin 138-139-140. paragraflarıdır. ${ }^{19}$

2001 tarihli Koruma Sorumluluğu Raporunda önlenme, tepki verme ve yeniden inşa başlığı altında açıklamalar yapılmışır. Raporda Güvenlik Konseyi'nin kuvvet kullanımı konusunda temel organ olduğu belirtildikten sonra Ruanda ya da Kosova'da olduğu üzere müdahale kararı alınamaması halinde Genel Kurul'un ve diğer bölgesel örgütlerin müdahale kararı alma olasılığı üzerinde durulmuştur. Raporda ayrıca, müdahale kararı alınması için bazı kriterler önerilmiştir. Bu kriterler, haklı sebep, doğru niyet, müdahaleden başka bir yolla ihlallerin sona erdirilmesinin mümkün olmaması, müdahale sırasında kullanılan araçların orantılı ve müdahaleden beklentilerin makul olmasıdır.

Keza, 2005 Dünya Zirvesi Sonuç belgesinde koruma sorumluluğunun üç tip sorumluluğu içinde barındırdığı belirtilmektedir. Birincisi, her devletin halkını soykırım, savaş suçları, insanlığa karşı suç ve etnik temizlikten koruma yükümlülüğü; ikincisi, uluslararası toplumun devletleri bu sorumluluklarını yerine getirmeleri için cesaretlendirmesi ve bu konuda yardımcı olması; üçüncüsü, bir devlet açıkça halkını koruyamıyorsa uluslararası toplumun BM Şartı'na uygun olarak kararlı bir şekilde, gecikmeksizin, ortak hareket etme konusunda hazırlıkı olmasıdır.

Güvenlik Konseyi, 2006 yılından bu yana aldığı yaptııım ya da barış gücü oluşturulmasına ilişkin 45 kararda koruma sorumluluğuna atıf yapmıştır. İnsan Hakları Konseyi'nin de bazı kararlarında koruma sorumluluğuna yer verdiği görülmektedir. Güvenlik Konseyi'nin koruma sorumluluğuna atıf yaptığı son karar, Ağustos 2016 tarihlidir ve Güney Sudan'a ilişkindir. ${ }^{20}$

Güvenlik Konseyi'nin koruma sorumluluğuna atıf yaparak aldığı kuvvet kullanmaya ilişkin ilk kararı Libya'ya ilişkindir. ${ }^{21}$ Güvenlik Konseyi, yine 2011 ylında aldığı Fildişi Sahilleri'ne ilişkin kuvvet kullanma

19 International Commission on Intervention and State Sovereignty, The responsibility to protect: report of the International Commission on Intervention and State Sovereignty (Ottawa: International Development Research Centre, 2001). General Assembly, World Submit Outcome Document, 14-15 September 2005, par.138,139,140.

20 South Sudan, UNSC Res 2304 (2016); bkz.

http://www.globalr2p.org/resources/335

${ }^{21}$ Libya, UNSC Res 1973 (2011). 


\section{Deniz Kızılsümer Özer}

kararında22 da koruma sorumluluğuna atıf yapmıştır (Breau, 2011). Güvenlik Konseyi'nin Libya kararı sonrasında doktrinde ileride de koruma sorumluluğunu gerekçesiyle birçok olaya müdahale kararı verebileceğine dair bir beklenti oluşmuştur (Bellamy ve Williams, 2011: 826; Thakur, 2011; Weiss, 2011: 292). Oysa yukarıda da belirttiğimiz üzere başta Suriye ve diğer ülkelerde ağır insan hakları ihlalleri gerçekleşmesine karşın koruma sorumluğu gerekçesi ile Güvenlik Konseyi'nden bir müdahale kararı çıkması mümkün olmamıştır. Koruma sorumluluğunun gerek uygulamada ortaya çıkan istikrarsızlıklar gerek kriterlerinin tam olarak netleşmemesi sebebiyle günümüzde bir uluslararası hukuk normu halinde gelmediği ifade edilmektedir (Hehir, 2013: 151; Sur, 2013: 25462548; Thakur ve Weiss, 2009).

Son olarak, Güvenlik Konseyi'nin koruma sorumluluğuna vurgu yaparak yaptıım ya da barışı koruma misyonlarına ilişkin kararlar aldığı görülmektedir. Ancak Güvenlik Konseyi'nden koruma sorumluluğuna dayanılarak açık bir müdahale kararı çıkmaması halinde koruma sorumluluğu devletlere BM Şartı'na aykırı olarak askeri müdahalede bulunma hakkı vermemektedir. Koruma sorumluluğu, Güvenlik Konseyi'nin kuvvet kullanımı konusundaki anahtar rolünü değiştirmemiştir. Güvenlik Konseyi'nde karar alınması sırasında sürekli üyelerin koruma sorumluluğunu da dikkate alarak oy kullanmaları beklenebilir. Ancak halen, Güvenlik Konseyi'nde veto yetkisine sahip devletlerin özellikle kuvvet kullanımına ilişkin bir karar alırken etik ya da değerlerden ziyade politik çıkarlarını üstün tuttukları görülmektedir.

Güvenlik Konseyi belli olaylara ya da yerlere ilişkin insan hakları ihlalleri yanında tematik ya da soyut olarak insan haklarının korunması yönünde de çalışmalar yapmıştır. Konsey'in silahlı çatışmalarda insan haklarının, kadınların ve sivillerin korunmasına, silahlı çatışmalarda cinsel şiddetin önlenmesine, silahlı çatışmalarda çocukların kullanılmasının kınanmasına yönelik aldığı önemli kararları bulunmaktadır ${ }^{23}$ (Connors ve Schmidt, 2014: 392; Higgins, 2016: 9-10).

22 UNSC Res 1975 (2011).

23 Silahlı çatışmalarda çocukların korunmasına ilişkin iliş̧in kararlar; UNSC Res 1539 (2004); UNSC Res 1612 (2005); UNSC Res 1885 (2009); UNSC Res 1820 (2008); silahlı çatışmalar sırasında cinsel şiddetin önlenmesine ilişkin kararlar; UNSC Res 1820 (2008), UNSC Res 1888 (2009), UNSC Res 1960 (2010), UNSC Res 2106 (2013). 


\section{İnsan Haklarının BM'nin Kurumsal Yapısı İçinde Korunması}

\section{Birleşmiş Milletler Genel Sekreteri}

BM Genel Sekreteri Güvenlik Konseyi'nin tavsiyesi üzerine Genel Kurul tarafından atanır ve "idari konularda Birleşmiş Milletler'in başkanlığını" yapar. ${ }^{24}$ Genel sekreterlerin çoğu kez devletlerle karşı karşıya gelmemek, uluslararası barış ve güvenliğin sağlanması amacına zarar vermemek için insan hakları ihlallerinde sessiz kaldıkları için eleştirildikleri görülmektedir. Genel sekreterlerin "sessiz diplomasi" yoluyla insan hakları ihlallerinin sona ermesi yönünde faaliyet gösterdikleri bilinmektedir. Genel sekreterlerden beklenen ise insan haklarını ilgilendiren konuların daha fazla Birleşmiş Milletler'in diğer organlarının önüne getirmeleridir (Forsythe, 2012: 85). Bununla beraber, Kofi Annan gelişme, barışın korunması ve çevre konularında çalışan bütün organların insan hakları meselelerini de temel almaları gereğini vurgulamıştır. Ayrıca Kofi Annan'ın güçlü İnsan Hakları Yüksek Komiserleri atadığı görülmüştür. Ban Ki-moon koruma sorumluluğu konusunda çalışmıştır (Alston ve Goodman, 2013: 692).

Genel sekreterler, İnsan Hakları Konseyi bünyesinde yaptıkları konuşmalarda da çeşitli insan hakları konularına değinmişlerdir. Bu konular arasında kadına karşı şiddet ve ayrımcılığın önlenmesi, insan hakları savunucularına uygulanan şiddet ve cinsel tercihler yer alır (Connors ve Schmidt, 2014: 394). Genel Sekreterlerin insan hakları ihlallerini içeren bazı olaylarda iyi niyet elçisi olarak görev yaptıkları ya da sorunlu bölgelere özel temsilcilerini atadıkları da görülmektedir. Örneğin, 2013'de İrlanda Eski Cumhurbaşkanı ve İnsan Hakları Komiseri Mary Robinson, Büyük Göller Bölgesine özel elçi olarak atanmıştır (Connors ve Schmidt, 2014: 395).

\section{Ekonomik ve Sosyal Konsey}

BM Şartı'nın 62(2) maddesinde Ekonomik ve Sosyal Konseyi'nin (ECOSOC) görevleri arasında insan hakları ve temel hürriyetlerinin gözetilmesi ve bunlara saygının sağlanması için tavsiyelerde bulunma yetkisi sayılmışırı.

Ancak Konsey'in daha önemli bir yetkisi devam eden paragrafta şu şekilde düzenlenmiştir. Konsey kendi yetkisi çerçevesindeki konularda Genel Kurul'a sunulmak üzere sözleşme taslakları hazırlar. Konsey bu fikra ile kendisine verilen yetki çerçevesinde yıllar içerisinde insan haklarının korunması alanında çok önemli insan hakları sözleşmelerinin hazırlanmasına öncülük etmiştir. Bu normatif faaliyetler ECOSOC

${ }^{24}$ Birleşmiş Milletler Şartı, m. 97. 


\section{Deniz Kızılsümer Özer}

bünyesinde İnsan Hakları Komisyonu tarafından gerçekleştirilmiştir. İnsan Hakları Komisyonu aşağıda ayrıntılı olarak inceleneceği üzere özellikle insan hakları normlarının geliştirilmesini, başka bir deyişle temel insan hakları sözleşmelerinin hazırlanmasını sağlamış; ayrıca İnsan Hakları Komisyonun tarafından insan hakları normlarına uyulmasını sağlamak üzere birtakım usuller geliştirmiştir.

\section{Uluslararası Adalet Divanı}

Birleşmiş Milletler'in asli organlarından Uluslararası Adalet Divanı (UAD) da özellikle son dönemde verdiği karar ve danışma görüşlerinde insan hakları ve insancıl hukuk sözleşmelerine atıf yapmaktadır. UAD'nin insan haklarına atıf yapan kararlarından ilki Güney Afrika'nın Namibya'da devam eden varlığına ilişkin 1975 tarihli danışma görüşüdür. Bu kararda, Güney Afrika'nın Namibya'yı işgalinin hukuka aykırı olduğu belirtildikten sonra üye devletler işgalci gücün hareketlerini tanımamaya ve destek olmamaya davet edilmiştir. Bunun neticesinde fili yönetime ambargo ve diğer sınırlamaların uygulanması söz konusu olmuştur. ${ }^{25}$ (Higgins, 2016: 10; Mertus, 2005: 47-48)

Ayrıca daha yakın tarihlerde, Bosna-Hersek'in Sırbistan'a karşı açtığı "BM Soykırım Sözleşmesinin Uygulanmasına İlişkin Dava"26 (Kızılsümer Özer, 2007) ve 2003 tarihli "İsrail'in İşgal Altındaki Filistin Topraklarında İnşa Etmekte Olduğu Duvar Konusundaki Danışma Görüşü"27 (Denk, 2007) insan hakları ihlallerine ilişkin önemli hükümler içermektedir. Özellikle, Kosova'nın bağımsızlık ilanının uluslararası hukuka uygun olup olmadığına ilişkin danışma görüşünde self-determinasyon hakkı ayrıntıı olarak ele alınmaktadır. Kosova'nın bağımsızlık ilanının uluslararası hukuka uygun olup olmadığına ilişkin danışma görüşünde ${ }^{28}$, somut olayın özellikleri ele alınarak ağır insan hakları ihlallerinin selfdeterminasyon hakkının kullanımasına sebep olabileceği belirtilmektedir. Ayrıca Divan'ın nükleer silahlara ilişkin danışma görüşünde ${ }^{29}$ de insan hakları vurgulanmaktadır (Martin vd., 2011: 11).

\footnotetext{
${ }^{25}$ Ayrıca, Western Sahara Opinion, 1975, Advisory Opinion, ICJ.

${ }^{26}$ Case Concerning the Application of the Convention on the Prevention and the Punishment of the Crime of Genocide, (Bosnia and Herzegovina v Serbia and Montenegro) 2007 ICJ.

27 Legal Concequences of the Construction of a Wall in the Occupied Palestinian Territory, Advisory Opinion 2003, ICJ.

${ }^{28}$ Accordance with international law of the unilateral declaration of independence in respect of Kosovo, 22 Temmuz, Advisory Opinion, ICJ.

29 Legality of the Threat or Use of Nuclear Weapons, 8 Haziran 1996, Advisory Opinion, ICJ.
} 


\section{İnsan Haklarının BM'nin Kurumsal Yapısı İçinde Korunması}

Uluslararası Adalet Divanı'nda görevli yargıçların insan hakları konusundaki hassasiyetleri dikkat çekmektedir. Bunun nedeni olarak, Divan yargıçlarının bu göreve gelmeden önce çoğunlukla aşağıda ele alacağımız özel usuller, bölgesel insan hakları mahkemeleri ya da andlaşma organlarında görevler yapmış olmaları gösterilmektedir (Connors ve Schmidt, 2014: 395). Uluslararası alanda insan haklarının korunmasına ilişkin görevlerde çalışan bu uzman kişiler önlerine gelen davalarda daha önce insan haklarının korunması konusunda kazandıkları deneyimlerden de yararlanmaktadırlar.

\section{Vesayet Konseyi}

Vesayet Konseyi günümüzde işlevsiz kalsa da temel görevi vesayet altındaki ülkelerin self-determinasyon haklarını kullanarak bağımsızıklarını kazanmalarını sağlamak olarak belirlendiği ve bu görevin gerekleri yerine getirildiği için insan haklarının gerçekleştirilmesine önemli ölçüde katkı yaptığı söylenebilir.

\section{INNSAN HAKLARININ KORUNMASINDA İNSAN HAKLARI KONSEYİ'NİN ETKİNLİĞİ}

İnsan Hakları Konseyi kurulmadan önce benzer bir tali organ olarak 1946-2006 yılları arasında "İnsan Hakları Komisyonu" faaliyet göstermiştir. 1946 yılında ECOSOC'un tali bir organı olarak kurulan İnsan Hakları Komisyonu'nun en önemli normatif başarısı İnsan Hakları Evrensel Bildirisi ve diğer temel insan hakları sözleşmelerinin hazırlanmasıdır. Komisyon'un diğer bir önemli görevi ise insan hakları ihlallerinin gerçekleştiği olay ve yerlerde incelemeler yapmak bunun neticesinde devletlere çeşitli tavsiyelerde bulunmaktı. ${ }^{30}$ Ancak Komisyon, özellikle Sosyalist ülkelerde gerçekleşen ihlallerin ele alınmadığı yönünde ciddi eleştirilere maruz kalmıştır. Keza, bazı ülkelerdeki insan hakları ihlallerinin denetlenmesi konusunda objektif olmadığına, temsil edilen devletlerin, hatta Komisyonun başkanlığını yapan siyasetçilerin ${ }^{31}$ (Donelly, 2013: 77) sebep oldukları insan hakları ihlallerine yönelik eleştiriler dikkate alınarak 2006 yllında Komisyon'un görevine son verilerek yerine "İnsan Hakları

30 Özellikle bu çerçevede 1967 yılında ECOSOC, 1235 sayılı kararı ile İnsan Hakları Komisyonu'na bazı ülkelerdeki insan hakları ihlallerini ele alma yetkisini vermiştir. 1970 yılında ise ECOSOC, 1503 sayılı kararı ile İnsan Hakları Komisyonu'na "insan hakları ve temel özgürlüklerin ağır ve yaygın ihlalleri konusunda şikayetlerin gizli olarak araştırılması yetkisi" vermiş̧ir. 1503 usulü 2006'da Konsey'in kuruluşu ile aşağıda ele alacağımız "şikayet usulü" adını almıştır.

31 Kaddafi'nin 2003 yılında Komisyon başkanlığına seçilmesi önemli bir örnektir. 


\section{Deniz Kızılsümer Özer}

Konseyi" kurulmuştur. ${ }^{32}$ İnsan Hakları Konseyi, Genel Kurul'a bağı bir tali organ olarak kurulmuştur. İnsan Hakları Konseyi 47 devletten oluşmakta ve üye devletler, Genel Kurul'da yapılan gizli oylamada oy çokluğu ile üç yıl için seçilmektedirler. Donnelly (2013: 162) 2010-2011 tarihlerinde Konsey'de temsil edilen devletlerin insan hakları sicillerinin iyi olmadığını vurgulamaktadır.

Komisyonun normatif alandaki başarısı temel insan hakları andlaşmalarının hazırlanmasıdır. Bu sözleşmeler, genel konulu sözleşmeler olarak nitelendirilen, 1966 Kişisel ve Siyasi Haklar Uluslararası Sözleşmesi ve Sözleşmenin Seçimlik Protokolü ile 1966 Ekonomik, Sosyal, Kültürel Haklar Uluslararası Sözleşmesi'nin hazırlanmasıdır; ayrıca özel konulu sözleşmeler olarak nitelenen 1965 "Her Türlü Irksal Ayrımclığın Ortadan Kaldırılmasına Dair Uluslararası Sözleşme"; Güney Afrika Cumhuriyeti'nde uygulanan apartheid rejimine karşı 1973 "Apartheid Suçunun Bastırıması ve Önlenmesine Dair Uluslararası Sözleşme"; 1979 "Kadınlara Yönelik Her Türlü Ayrımcılığın Ortadan Kaldırılmasına Dair Sözleşme", 1999'da Sözleşme'nin Seçimlik Protokolü; 1984 "İşkence ve Diğer İnsanlık Dışı ya da Aşağılayıcı Muamele veya Cezaya Karşı Sözleşme", 2002 Sözleşme'nin Seçimlik Protokolü; 1989 "Çocuk Hakları Sözleşmesi" 2000 "Silahlı Çatışmalara Katılan Çocuklara İlişkin Seçimlik Protokolü ve Çocuk Satışı, Çocuk Fahişeliği ve Çocuk Pornografisi Seçimlik Protokolü, Çocukların Haberleşmesine İlişkin Seçimlik Protokolü"; 1990 "Göçmen İşçilerin ve Ailelerinin Haklarının Korunmasına Dair Uluslararası Sözleşme"; İnsan Hakları Konseyi tarafından hazırlananlar ise; 2006 "Engelli Kişilerin Haklarına Dair Sözleşme", aynı yıl Sözleşme'nin Seçimlik Protokolü; 2006 "Herkesin Zorla Kaybedilmeye Karşı Korunması Uluslararası Sözleşmesi" Komisyon daha sonra da Konsey tarafından hazırlanmışlardır. ${ }^{33}$ Uluslararası alanda insan haklarının normatif açıdan geliştirilmesi İnsan Hakları Konseyi tarafından sağlanmıştır.

Ayrıca, bu sözleşmelerde yer alan hakların uygulanmasını sağlamak üzere sözleşmelerle aynı adı taşıyan komiteler kurulmuştur. Andlaşma komiteleri, BM'nin tali organı sayılmasalar dahi makalede belli bir bütünlük sağlanmak amacıyla kısaca haklarında bilgi verilecektir. Komitelerde bağımsız insan hakları uzmanları görev yapmaktadır. Bu komitelerin görevleri, taraf devletlerden gelen ilgili sözleşme gereği yapılan faaliyetlerin belirtildiği raporların incelenmesi, değerlendirilmesidir. Bu raporların incelenmesi sonucunda komiteler, taraf devletlerin sözleşmelerden doğan yükümlülüklerini yerine getirip

32 UNGA Res 60/251, 15 Mart 2006.

33 Bkz. http://www.unicankara.org.tr 


\section{İnsan Haklarının BM'nin Kurumsal Yapısı İçinde Korunması}

getirmediğine ilişkin sonuç gözlemlerini (concluded observations) yayınlamaktadırlar. Komiteler ayrıca, sözleşme kapsamındaki konularda yapılan bireysel başvuruları değerlendirmekte; ülkelerde yerinde incelemelerde bulunmakta; devletlerarası başvuruları değerlendirmekte; sözleşme hükümlerinin ne şekilde uygulanacağına ve yorumlanacağına ilişkin genel yorumlar (general comments) yapmaktadırlar. Komite kararlarının yargısal niteliği bulunmamaktadır. Bu sebeple hukuken bağlayıcı değildirler. Ancak kararların yarı-yargısal nitelikte olduğu ve uluslararası ve ulusal düzeyde insan hakları hukukuna önemli katkılarının bulunduğu kabul edilmektedir (Buergenthal, 2006: 789-790; Dündar Sezer, 2013; Gülmez, 2004; Kızılsümer Özer, 2014: 362; Shaw vd., 2008: 307; Steiner, 2010: 791).

İnsan Hakları Konseyi'nin insan hakları normlarının oluşturulması görevi devam etmektedir. Normların oluşturulması yanında İnsan Hakları Konseyi'nin insan hakları ihlallerinin önlenmesi, gerçekleşen insan haklarının sona erdirilmesi, adaletin sağlanması ve hukuk devletinin gerçekleştirilmesi yönünde önemli faaliyetleri söz konusudur. Günümüzde, Konsey'in normatif çalışmaları arasında, çok tartışmalı olan insansız hava araçlarının terörizmle mücadele için kullanılması, kitlesel izleme gibi konular yer almaktadır (Higgins, 2016: 10).

Konsey çeşitli yollarla insan hakları ihlalleri alanında çalışmalar yapmaktadır. Bu yollar sırası ile özel usuller ve evrensel periyodik gözden geçirme mekanizması, şikayet usulü başlıkları altında incelenecektir. İncelemeye başlamadan önce evrensel periyodik gözden geçirme mekanizmasının ve şikayet usulünün İnsan Hakları Komisyonu'nun denetim faaliyetlerine yapılan çeşitli eleştirileri ortadan kaldırmaya yönelik olduğu belirtilmelidir. Yukarıda kısaca değindiğimiz üzere bu eleştiriler İnsan Hakları Komisyonu'nun ihlalleri seçici bir şekilde ele alması ve politize olduğu yönündeydi.

Genel olarak, yollar neticesinde hazırlanan raporlarda kapsamlı bilgi ve tavsiyeler yer almaktadır. Raporların dili uzlaştırıcı ya da ilgili devletin ihlal tespiti karşısındaki tavrı dikkate alınarak eleştirel de olmaktadır. Belirtilmelidir ki, Konsey tarafından alınan kararların tavsiye niteliğinde olması bu yolların etkinliğini azaltmaktadır (Steiner, 2010: 792-793).

\section{Özel Usuller}

Bünyesinde özel usullerin (special procedures) kurulması İnsan Hakları Komisyonu'nun en önemli başarılarından biri olarak kabul edilmektedir. Özel usuller çerçevesinde 1980 yılından itibaren aşağı yukarı bütün devletleri ilgilendiren insan hakları ihlalleri konusunda çalışmalar 


\section{Deniz Kızılsümer Özer}

yapılmışıı ${ }^{34}$ (Connors ve Schmidt, 2014: 397). Özel usuller çerçevesinde, belli devletlerdeki insan hakları ihlallerinin (ülke görevi) ya da çeşitli ülkelerde gerçekleşen ihlallerin ele alındığı bazı tematik konuların incelenmesi (tematik görev) için raportörlerin görevlendirilmesi ya da çalışma gruplarının oluşturulması söz konusudur (Freeman, 2013: 282).

Özel usullerin en önemli özelliği çalışmaların siyasetçi ya da bürokratlardan farklı olarak insan hakları alanında çalışan uzmanlarca gerçekleştirilmesidir. Bu durum özel usullerin saygınlığını arttırmaktadır. Uzmanlar ve tarafsız, siyasi kimliği olmayan kişiler, spesifik insan hakları konularında çalışmış olmaları sebebiyle konulara hakim olmakta, siyasi baskılardan uzak bir şekilde faaliyetlerini gerçekleştirebilmektedir. Uygulamada, bu görevlerin daha çok akademisyenler tarafından gerçekleştirildiği görülmektedir (Banketas ve Oette, 2013: 161; Donnelly, 2013a: 79). Bu kişiler Haziran 2007'de İnsan Hakları Konseyi tarafından benimsenen "Özel Usuller Çerçevesinde Görevlendirilen Kişiler için Davranış Kodu"na ${ }^{35}$ uygun hareket etmelidirler. Davranış Kodu ile özel usullerin etkinliğinin ve burada görev alan kişilerin etik ve profesyonel davranmalarının sağlanması amaçlanmaktadır (Connors ve Schmidt, 2014: 397).

Özel prosedürler çerçevesinde görevlendirilen kişiler, ülke ziyaretlerinde bulunmakta, ziyaretlerde insan hakları savunucularından gelen şikayetleri incelemekte, etkili görüş ve standartlar geliştirmekte ve insan hakları konularında bilinçlenme sağlamaktadırlar. (Connors ve Schmidt, 2014: 368-269). Steiner'a (2010: 793) göre, devletler tematik incelemelere, bu araştırmalarda yalnızca belli bir devlet ülkesindeki ihlaller ele alınmadığı için daha sıcak bakmaktadırlar.

Bu çerçevede, 30 Haziran 2016 itibariyle 14 ülke görevi ve ayrıca 42 tematik görev gerçekleştirilmiştir. ${ }^{36}$ Ülke görevleri, Beyaz Rusya, Kamboçya, Orta Afrika Cumhuriyeti, Eritre, Fildişi Sahili, Kore Demokratik Halk Cumhuriyeti, Ruanda, Liberya, Romanya, Afganistan, Haiti, İran İslam Cumhuriyeti, Mali, Myanmar, Filistin, Sudan, Somali, Sri Lanka, ve Suriye'de gerçekleşmiştir. Ülke görevlerinin özel raportörler aracılığı ile gerçekleştiği görülmektedir.

Özel usuller çerçevesinde, ayrıca tematik ihlaller de incelenmektedir. Burada bir devlet nezdinde araştırma yapmak yerine

${ }^{34}$ CommHR resolution 20(XXXVI), 29 Şubat 1980.

35 Code of Conduct for Special Procedures Mandate Holders, HR Council Res 5/1 (18 June 2007).

36 Special Procedures of the Human Rights Council, http://www.ohchr.org/EN/ HRBodies/SP/Pages/Introduction.aspx 


\section{İnsan Haklarının BM'nin Kurumsal Yapısı İçinde Korunması}

çeşitli ülkelerdeki yaygın ve ağır ihlaller incelenmektedir. Bu çerçevede, keyfi tutuklamalar, işkence, yargısı infaz, kadına karşı şiddet, silahlı çatışmada çocuklar, aşırı yoksulluk ve insan hakları, kaybolmalar, emniyetli, temiz, sağlıklı, sürdürülebilir çevre, paralı askerler, yargıçların bağımsızlığı, eğitim, gıda, sağlık, su hakkı, din hürriyeti, kültürel haklar, yaşılıarın hakları, özel hayatın gizliliği, dış borçların etkileri konusundaki ihlaller incelenmiştir. 2015 yılında başlayan son tematik görev ile Afrika'da yaygın olarak karşılaşılan albinoların temel haklarının ihlaline yönelik uygulamaların önlenmesi amaçlanmaktadır. ${ }^{37}$ Özellikle, özel usuller çerçevesinde gerçekleştirilen işkence, yargısız infaz ve kadına karşı şiddet konularındaki çalışmaların başarılı olduğu vurgulanmaktadır (Donnelly, 2013a: 13, 79).

\section{Evrensel Periyodik Gözden Geçirme Mekanizması}

Evrensel Periyodik Gözden Geçirme Mekanizması (EPGGM) ${ }^{38}$ ile bütün devletlerin verdikleri insan hakları raporları yoluyla izlenmesi, bu yolla küresel olarak insan haklarının geliştirilmesi amaçlanmaktadır. EPGGM de Komisyon'a yöneltilen seçicilik ve politize olmaya iddialarına karşı Konsey bünyesinde insan haklarının korunması ve geliştirilmesi görevini yerine getirmek için oluşturulmuş bir mekanizmadır. Seçicilik iddiası Komisyon'un bazı yerlerdeki insan hakları ihlallerini ele alırken bazı yerlerdeki insan hakları ihlallerine gereken önemi vermediğine eleştirilerine dayanmaktadır. Ayrıca devletlerin Konsey çalışmaları sırasında insan haklarının geliştirilmesi amacıyla değil de siyasi saiklerle hareket etmeleri de önemli bir eleştiri konusu olmuştur. Bu eleştirileri bertaraf etmek amacıyla getirilen EPGGM çerçevesinde BM üyesi bütün devletler, 20 sayfayı aşmayacak bir raporu dört ya da beş yıl arayla Konsey'e göndermektedirler. Raporda, ülkelerinde insan haklarının geliştirilmesine yönelik ve insan haklarına ilişkin yükümlülüklerini yerine getirmek için gerçekleştirdikleri faaliyetleri ve insan haklarının genel durumu yer alacaktır. Bu raporların hazırlanması sırasında devletlerden sivil toplum örgütleri ile birlikte çalışmaları beklenmektedir. Daha sonra, devletlerden göndermiş oldukları raporları kendilerine verilen zaman içinde sorulacak sorular çerçevesinde savunmaları beklenmektedir. Bu sayede yalnızca Konsey tarafından ele alınması kararlaştırılan ağır insan

37 Independent Expert on the enjoyment of human rights by persons with albinism, 2015, HRC resolution A/HRC/RES/28/6.

38 Universal Periodic Review Mechanism (Evrensel Periyodik Gözden Geçirme Mekanizması) 15 Mart 2006 tarihinde Genel Kurul'un 60/251 sayılı kararı ile kurulmuştur. 


\section{Deniz Kızılsümer Özer}

hakları ihlalleri ile suçlanan hükümetlerin değil bütün devletlerin verecekleri raporlarla Konsey'in önüne gelmesi sağlanmıştır. Bu çerçevede yapılacak incelemelerin siyasi olmaktan ziyade teknik olacağı öngörülebilir (Freeman, 2013: 253).

Burada özel usullerden farklı olarak uzmanların değil eşitlerin birbirini denetlemesi (peer review) olarak nitelenebilecek devletlerin birbirlerinin denetlemeleri söz konusudur. Belli bir devletin raporunun gözden geçirilmesi için 47 Konsey üyesi devlet arasından üç devlet, oluşturulacak çalışma grubuna raportör olarak atanmak üzere kura seçilir. ${ }^{39}$

Devletler tarafından gönderilen raporun incelenmesi aşamasında iki ayrı kaynaktan gelen bilgilere de bakılır. Bunlardan ilki ilgili andlaşma organlarının, özel usullerin raporları, diğer BM belgeleri diğeri ise paydaşlar ve sivil toplum örgütlerinden gelen raporlardır. Her iki kaynaktan gelen belgeler 10 'ar sayfayı aşamazlar. Devlet ile çalışma grubu arasında "yapıcı bir diyalog" beklenmektedir. Bu diyaloğa sivil toplum örgütleri soru sorma hakları olmadan katılabilirler. Üç saat süren toplantıda çalışma grubu önemli konuları masaya yatırır; önerilerde bulunur. Hükümet de hangi önerileri kabul edip etmediğini açıklar. Gözden geçirmenin sonucuna ile ilgili devletle uzlaşma sağlanarak bazı tavsiyelerin yer aldığı bir "sonuç raporu" hazırlanır (Alston ve Goodman, 2013: 737, 738; Banketas ve Oette, 2013: 156). Bu usul sayesinde, denetleme neticesinde çıkacak sonucu ilgili devletin büyük ölçüde etkilemesi mümkün olmaktadır.

EPGGM, devletlerin iş birliği içinde hareket edecekleri, şeffaflığı sağlayıcı, devletleri karşı karşıya getirmeyen, yarı-yargısal olarak dahi nitelenemeyen bir yöntemdir. EPGGM ile devletlerin yargılanması ya da kınanması yerine insan haklarını iyileştirmeye yönelik çözüm önerilerinin getirilmesi, en iyi örneklerin paylaşılması, teknik yardım ve kapasite geliştirilmesi amaçlanmaktadır. Bu çerçevede, sorunların belirlenmesi ve bunlarla başa çıkılması temel amaçtır. Devletlerin uygulamalarına bakıldığında ise en azından bazı tavsiyeleri dikkate alarak gerekli uygulama ve yasal değişiklikleri yaptıkları görülmektedir (Banketas ve Oette, 2013: 157). Devletlerin sonuç raporunda yer alan tavsiyelere uymaması halinde İnsan Hakları Konseyi tarafından "iş birliğinden sürekli

39 Universal Periodic Review, http://www.ohchr.org/EN/HRBodies/UPR/Pages/ UPRMain.aspx. 


\section{İnsan Haklarının BM'nin Kurumsal Yapısı İçinde Korunması}

kaçan devlet" olarak nitelenerek haklarında bazı tedbirlerin uygulanması mümkün olmaktadır. ${ }^{40}$

Bu mekanizma, özellikle Komisyon'un incelemeye alınan ihlaller konusunda seçici olduğuna, bazı ihlalleri gündemine almadığına ilişkin eleştirileri gidermek amacıyla geliştirilmiştir (Shaw, 2008: 307).

\section{Şikayet Usulü}

2007 yılında İnsan Hakları Konseyi tarafından Dünya'nın çeşitli yerlerinde ortaya çıkabilecek ağır insan hakları ihlallerine karşı başvurulabilecek bir şikayet mekanizması oluşturulmuştur. Şikayet usulü, 1503 usulünün yerine oluşturulmuştur ve 1503 usulü gibi gizlilik ve ilgili hükümetle iş birliği esasına dayanmaktadır. ${ }^{41}$

Şikayet usulü, özellikle 1503 usulüne getirilen eleştiriler dikkate alınarak tarafsız, objektif, mağdurları temel alan ve süratli karar verecek bir mekanizma olarak düzenlenmiştir. Şikayet usulü, insan hakları ihlallerinin mağduru iddiasındaki ya da ihlaller konusunda güvenilir bilgiye sahip bireyler, gruplar ya da sivil toplum kuruluşları tarafından başlatılabilir. Şikayet usulünün diğer bireysel başvuru usullerinden önemli bir farkı bulunmamaktadır. Öyle ki, medyadan alınan bilgilere ya da ikinci elden elde edinilen bilgilere dayanılarak dahi başvuru yapılabilmektedir. En önemli kabul edilebilirlik kriteri, başvuruların siyasi amaçlı olmamasıdır. İç başvuru yollarının tüketilmesine gerek bulunmamakla beraber olayın şikayet sırasında diğer bir insan hakları usulü çerçevesinde incelenmemesi gerekmektedir. Kabul edilebilirlik kararı alındıktan sonra iddialar, gerekli soruşturma yapılmak üzere çalışma gruplarına gönderilmektedir. Şikayet usulü sonrasında beş farklı karar verilebilmektedir. Bu kararlar, usulün tamamen sonlandırımasına, devletten daha fazla bilgi isteyerek gözden geçirmenin devam etmesine, ülke raportörü atayarak gözden geçirmenin devamına, gizliliği kaldırılarak olayın kamuoyunun bilgisine sunulmasına, son olarak da teknik yardım, kapasite oluşturulması konusunda tavsiyelerde bulunulmasına ilişkin olabilir (Banketas ve Oette, 2013: 159160).

Günümüze kadar, Kamerun, Eritre, Irak, Kongo Demokratik Cumhuriyeti, Türkmenistan, Tacikistan, Gine, Maldivler, Türkmenistan,

\footnotetext{
40 Basic Facts About the UPR, http://www.ohchr.org/EN/HRBodies/UPR/Pages/ BasicFacts.aspx.

411503 Usulü, 1970 yılında Ekonomik ve Sosyal Konsey'in aldığı 1503 sayılı karar ile İnsan Hakları Komisyonu'na "İnsan hakları ve temel özgürlüklerin ağır ve yaygın ihlalleri hakkındaki şikayetlerin gizli olarak araştırılması yetkisi" verilmiştir. Human Rights Council Complaint Procedure, http://www.ohchr.org/EN/HRBodies/ HRC/ComplaintProcedure/Pages/HRCComplaintProcedureIndex.aspx
} 


\section{Deniz Kızılsümer Özer}

Özbekistan, İran, Kırgızistan'da meydana gelen insan hakları ihlal iddiaları şikayet usulü çerçevesinde değerlendirilmiştir. ${ }^{42}$

Günümüzde Konsey'in denetim faaliyetleri bütün bu yeni oluşturulan mekanizmalara karşın eleştirilmekte; insan haklarının korunmasında başarılı olmadığı ileri sürülmektedir. Özellikle, selefi Komisyon'a yöneltilen eleştirilerin Konsey bakımından da devam ettiği görülmektedir. Bu çerçevede, Konsey'in politize olduğuna ve insan haklarını koruma ve geliştirme hedefinden daha çok siyasi amaçlar çerçevesinde hareket ettiğine ilişkin iddialar devam etmektedir. Öyle ki, evrensel periyodik gözden geçirme mekanizması incelemelerinde özellikle, ülkelerin raporlarını savunurken daha önce anlaştığı ülkelerden gelecek sorularla sürelerini doldurmaları ve ciddi soruların sorulmasına fırsat dahi vermedikleri yönünde tespitler yapılmıştır (Freeman, 2013: 253).

Ancak günümüzde de İnsan Hakları Konseyi'nde devlet temsilcilerinin bulunması, yapılacak değerlendirmelerde politik çıkarların üstün tutulabileceği sebebi ile eleştirilmektedir (Forsythe, 2006: 6). Özellikle Çin ve İsrail tarafından gerçekleştirilen ihlallerin Konsey'de yeterince ele alınmadığı belirtilmektedir (Donnelly, 2013a: 162). Ayrıca, devletler bölgesel ittifaklar ya da kolektif ajandalar oluşturmak suretiyle Konsey çalışmalarını bloke edebilmektedirler. Burada özellikle Afrika Grubu ve İslam İş Birliği Örgütü'nün faaliyetleri Freeman (2013: 299) tarafından vurgulanmıştır. Bu sebeple, Konsey birçok önemli insan hakları ihlali ile ilgilenemez hale gelmiştir. Diğer bir eleştiri olarak da, Konsey'de yapılan eleştirilerin amacını aşmasından, bazı devletlerin ise özellikle isim verilerek suçlanmasından söz edilmektedir.

\section{Uluslararası Soruşturma Komisyonları}

İnsan Hakları Konseyi yanında Genel Kurul, Güvenlik Konseyi, Genel Sekreter, İnsan Hakları Yüksek Komiserliği de insan hakları ihlallerinin araştırımasına yönelik uluslararası soruşturma komisyonlarının kurulmasına öncülük edebilmektedir. Soruşturma komisyonları süregelen ya da aniden patlak veren ciddi insan hakları ya da insancıl hukuk ihlallerinin tespiti için görev yapmaktadırlar. Komisyonların amacı, insan hakları ihlallerinin ortaya çıkmasını sağlamak, ihlaller sebebiyle hesap verilebilirliğin sağlanması ve insan hakları ihlallerine karışan kişilerin dokunulmazlıklarının ortadan kaldırımasıdır. Yargısal niteliği olmamakla beraber hukuki ve olgusal durumları inceleyerek durumun iyileştirilmesi

42 List of Situations Referred to the Human Rights Council under Complaint Procedure since 2006: http://www.ohchr.org/Documents/HRBodies/Complaint Procedure/SituationsConsideredUnderComplaintProcedures.pdf 


\section{İnsan Haklarının BM'nin Kurumsal Yapısı İçinde Korunması}

için tavsiyelerde bulunulmaktadır. ${ }^{43}$ İlk olgu-tespiti (fact-finding) 1963 yılında Vietnam, son bağımsız soruşturma ise Burundi için 2015 yılında yapılmıştır. Soruşturma komisyonları, ayrıntılı incelemelerle insan hakları hukukunun özellikle uygulanmasını sağlamaktadır. Ayrıca, hazırlanan raporların mağdurlara tazminat ödenmesinin, sorumluların cezalandırıması için hukuk yollarının oluşturulmasının sağlanması gibi uygulamaya yönelik etkileri olmaktadır. Bunun yanında hazırlanan raporların, ad hoc mahkemelerce ya da Uluslararası Ceza Divanı'nca kullanılması söz konusu olmakta; barış inşa süreci ve uzlaşmanın, çatışmaların siyasi çözümlerinin kalıcılığı için adaletin sağlanması gibi etkileri olabilmektedir. Ayrıca, incelenen konuya ilişkin olarak kamuoyunun oluşturulması, başka yollardan haklarını alamayacak mağdurların haklarını almalarının sağlanması uluslararası soruşturma komisyonlarının çalışmaları ile mümkün olmaktadır. ${ }^{44}$ Esasen uluslararası alanda olgu-tespiti birçok uyuşmazlığın daha fazla uzamadan, derinleşmeden çözülmesini sağlamaktadır. Günümüzde insan hakları ihlallerinin tespitinde de olgu-tespitinden yararlanılması ve bu yolla insan hakları konusunda iyileştirmenin ve adaletin sağlanması önemli bir gelişme olarak nitelenebilir.

\section{İNSAN HAKLARI KONUSUNDA FAALİYET GÖSTEREN DİĞER TALİ ORGANLAR}

Birleşmiş Milletler temelde asli organları, İnsan Hakları Konseyi ile insan haklarının korunmasına çalışırken, ayrıca Kadın Statüsü Komisyonu ve Konsey'in alt organı olarak İnsan Haklarının Korunması ve Geliştirilmesi Alt-Komisyonu oluşturulmuştur. Bu çerçevede bir tali organ olarak BM Mülteciler Yüksek Komiserliği'nin (UNHCR) ve BM Sekreteryası bünyesindeki İnsan Hakları Yüksek Komiseri'nin faaliyetleri de önemlidir.

\section{İnsan Hakları Yüksek Komiserliği ${ }^{45}$}

BM İnsan Hakları Yüksek Komiserliği, 1993 Viyana Dünya Konferansından sonra kurulmuş ve ilk Komiser 1994 ylında atanmıştır. Komiser, BM'de insan haklarından sorumlu Genel Sekreter yardımcısı olarak görev yapmaktadır. Komiserin görevleri, hakların korunması ve

43 International Commissions of Inquiry and Fact-finding Missions, http://libraryresources.unog.ch/factfinding.

44 Commisions of Inquiry and Fact-finding Missions on International Human Rights Law and Humanitarian Law. Guidance and Practice, UN Office for Human Rights, Office of the High Commissioner, 2015, s.7

45 The Office of the High Commissioner of Human Rights., GA Res, 48/141, 1993. 


\section{Deniz Kızılsümer Özer}

haklardan etkin yararlanılmasının sağlanması konularında devletlere teknik yardımda bulunmak, insan haklarına saygının sağlanması için hükümetlerle diyalog içinde olmak, iş birliğini geliştirmek olarak belirlenmiştir. Komiserler, özellikle ulusal alanda insan hakları kurumlarının oluşturulması ve geliştirilmesi konusuna önem vermektedirler. Komiserliğin en temel görevi, Birleşmiş Milletler mekanizması içinde bütün insan haklarına ilişkin faaliyet gösteren bütün birimler arasında koordinasyonun sağlanmasıdır. Bu görevi çerçevesinde Komiserlerin bazen sessiz diplomasi yürüttüğü, kimi zaman ise kamunun önünde insan haklarını savunduğu olduğu görülmektedir. Komiserliğin politize olmaması ve ağır bürokrasi çerçevesinde çalışmaması, doğrudan hükümetlerle görüş̧ebilmesi sayesinde etkin bir şekilde çalıştığı ifade edilmektedir. Komiserliğin çeşitli ülkelerde büroları bulunmaktadır. Komiserlik, ayrıca barış gücü misyonları görevlilerini de insan haklarının gözetilmesini sağlamak üzere görevlendirmektedir (Chesterman vd., 2016: 479; Steiner, 2010: 796).

\section{Kadın Statüsü Komisyonu}

Kadın Statüsü Komisyonu, 1946 yllında Ekonomik ve Sosyal Konsey'e bağı ıir hükümetler arası organ olarak kurulmuştur. ${ }^{46}$ Komisyon'un temel amacı, cinsiyet eşitliğinin sağlanması ve kadınların güçlendirilmesidir. Komisyon'un kadın haklarının geliştirilmesi, cinsiyet eşitliği ile ilgili evrensel standartların belirlenmesi, kadınların yaşamsal gerçeklerinin belgelenmesi yönünde önemli faaliyetleri söz konusudur. Komisyon, esasen çalışmalarını cinsiyet eşitliği üzerine temel bir belge olan 1995 Pekin Bildirisi ve Hareket Platformu ${ }^{47}$ çerçevesinde yürütmektedir.

\section{İnsan Haklarının Korunması ve Geliştirilmesi Alt-Komisyonu ${ }^{48}$}

Alt-Komisyonun ilk adı "Azınlıkların Korunması ve Ayrımcılığın Önlenmesi Alt-Komisyonu" idi. Alt-Komisyon 26 bağımsız insan hakları uzmanından oluşmaktadır. Alt-Komisyon şimdiye değin insan haklarının gerçekleştirilmesi için adalet sistemlerinin iyileştirilmesi, ayrımcılıkla mücadele, azınlıkların, yerli halkların ve diğer hassas grupların korunması ile ilgili çalışmalar yapmıştır. Alt-Komisyonun çalışmaları genellikle

\footnotetext{
46 Council Resolution of 11(II), 21 June 1946. Komisyonun görevleri 1996 yılında ECOSOC resolution 1996/6 ile genişletilmiştir.

471995 Beijing Declaration and Platform for Action.

${ }^{48}$ Sub-Commission on the Promotion and Protection of Human Rights.
} 


\section{İnsan Haklarının BM'nin Kurumsal Yapısı İçinde Korunması}

tavsiyeler hazırlanması yönündedir; çoğu kez bir düşünce kuruluşu gibi faaliyet gösterdiği ifade edilmektedir. ${ }^{49}$

\section{Birleşmiş Milletler Mülteciler Yüksek Komiserliği}

Birleşmiş Milletler Mülteciler Yüksek Komiserliği (BMMYK) 14 Aralık 1950'de BM Genel Kurulu tarafından kurulmuştur; amacı, mültecilerin korunması, uluslararası hareketlerin düzenlenmesi ve dünya çapında mülteci sorunlarının çözülmesidir. Bu çerçevede, mültecilerin haklarını korunması ve refahlarının sağlanması Yüksek Komiserliğin en önemli görevleridir. Keza, iltica taleplerinin değerlendirilmesi ve diğer bir devlete gönüllü geri dönüşün sağlanması, yerel bütünleşmenin ya da üçüncü bir ülkeye yerleştirmenin güvenli bir şekilde sağlanması, keza mültecilerin barınma haklarını kullanmalarının sağlanması; zorla yerinden edilme vakalarını azaltılması, amaçları arasındadır. Bu doğrultuda BMMYK, kendi ülkelerine dönen mültecilerin yeniden kaynaşmalarını sağlamaya ve mülteci yaratabilecek olayların tekrarlanmasını önlemeye çalışmaktadır. BMMYK, ırk, din, politik düşünce ve cinsiyet ayrımı yapmaksızın mültecilere ve yerinden edilmiş kişilere koruma ve yardım sağlamaktadır. BMMYK, bütün faaliyetleri arasında mesaisini büyük oranda çocukların ve kadınların yaşamlarını kolaylaştırmaya ve haklarını kullanmalarını sağlamaya ayırmaktadır. ${ }^{50}$

Bir BM bağımsız uzman kurum olarak kurulmuş olan Uluslararası Mülteciler Örgütü'nün (IRO) ${ }^{51}$ daha sonra BMMYK adını alarak BM'nin tali bir organı haline gelmesi eleştirilebilir. Ancak BMMYK, günümüzde mültecilerin korunmasında oldukça etkin bir organ olarak kabul edilmektedir. BM Yüksek Komiserliğini bölgesel ya da daha dar alanlarda faaliyet gösterecek bürolar açması halinde daha etkin çalışabileceği de ileri sürülmektedir (Connors ve Schmidt, 2014: 396).

Son olarak Buergenthal'e (2007: 795-797) göre, Şart'a dayanan sistemin en önemli zaafı politize olma iddialarıdır. Bazı ülkelerdeki insan hakları ihlalleri organlarda sürekli olarak eleştirilerken, bazıları aynı dikkati çekmemektedir. Devletler, temsil edildikleri Birleşmiş Milletler organlarındaki tutumlarını çoğu zaman siyasi kaygılarla belirlemektedirler.

49 İnsan Haklarının Korunması ve Geliştirilmesi Alt-Komisyonu; http://www.ohchr.org/EN/HRBodies/SC/Pages/SubCommission.aspx

50 United Nations High Commissioner for Refugees (UNHCR).

${ }^{51}$ International Refugee Organisation (1946-1952). 


\section{Deniz Kızılsümer Özer}

\section{SONUÇ}

Birleşmiş Milletler asli ve tali organları görev ve yetkileri içinde insan haklarının geliştirilmesi ve koruması amacı çerçevesinde gerek normatif gerek uygulama alanında önemli faaliyetlerde bulunmuştur. Birçok açıdan başarılı bulunan bu faaliyetler bazı bakımlardan eleştirilmektedirler. Bu eleştiriler, özellikle, organların insan haklarına ilişkin işlevlerini yerine getirirken politize olmalarına, bu sebeple özellikle denetleme yollarının kendilerinden bekleneni veremediğine ilişkindir. Son yıllarda, bu eleştirilerin dikkate alınarak Güvenlik Konseyi müeyyidelerinin şekil değiştirdiği, İnsan Hakları Komisyonun İnsan Hakları Konseyi haline geldiği, evrensel periyodik gözden geçirme, şikayet usulü gibi yeni yolların getirildiği görülmektedir. Kanımca, politize olma iddialarını gidermenin en iyi yolu insan hakları ihlali iddialarının siyasetçiler yerine uzman kişilerce değerlendirilmenin sağlanmasıdır.

Politize olma eleştirileri yanında Birleşmiş Milletler bünyesinde insan haklarının korunması için faaliyet gösteren çok sayıda yolun ve organın bulunması da eleştirilebilir. Özellikle hakların ihlalinin denetlenmesine ilişkin olarak benzer konularda, ayrı ayrı çok sayıda çalışma yapılması organların ve yolların etkin ve verimli çalışmasını engelleyebilmektedir. Özellikle, Birleşmiş Milletler Genel Sekreteri ve İnsan Hakları Yüksek Komiseri'nin bütün bu çalışmaların koordinasyonu konusunda çalışması yararlı olacaktır.

\section{KAYNAKÇA}

Alston, P. ve Goodman, R. (2013). International Human Rights - The Successor to International Human Rights In Context. Oxford: Oxford University Press.

Arsava, A.F. (2007). Birleşmiş Milletler Güvenlik Konseyi Kararlarına Karşı İnsan Hakları Himayesi. UHP, 3(10).

Baehr, P.R. ve Castermans-Holleman, M. (2004). The Role of Human Rights in Foreign Policy. New York: Palgrave Macmillan.

Banketas, I. ve Oette, L. (2013). International Human Rights Law and Practice. Cambridge: Cambridge University Press.

Bellamy, A.J. ve Williams, P.D. (2011). The New Politics of Protection? Côte d'Ivoire, Libya, and the Responsibility to Protect. International Affairs, 87(4). 


\section{İnsan Haklarının BM'nin Kurumsal Yapısı İçinde Korunması}

Bossuyt, M. (2016). International Human Rights Protection. Intersentia, Cambridge.

Breau, S. (2011). The Situation in Ivory Coast: Intervention to Protect or regime change Operation, https://internationallawnotepad.wordpre ss.com/2011/04/11/situation-ivory-coast-intervention-regimechange/

Buergenthal, T. (2006). The Evolving International Human Rights System. American Journal of International Law, 100(4).

Charron, A. (2013). UN Sanctions and Conflict. London and New York: Routledge.

Chesterman, S. vd. (2016). Law and Practice of the UN. Oxford: Oxford University Press, 477-514.

Connors, J. ve Schmidt, M. (2014). United Nations. Moeckli, D., Shah, S. ve Sivakumaran, S. (Der.), International Human Rights Law. Oxford: OUP.

Cortright, D. ve Lopez, G.A. (2002). Sanctions and the Search for Security, Challenges to UN Action. London: Lynner Rienner Publishers.

Denk, E. (2004). Uluslararası Adalet Divanı́nın İsrail'in İşgal Altındaki Filistin Topraklarında İnşa Etmekte Olduğu Duvar Konusundaki Kararı. Uluslararası İlişkiler, 3, 151-173.

Donnelly, J. (2013a). Universal Human Rights in Theory and Practice. New York: Westwiew Press.

Donnelly, J. (2013b). International Human Rights. New York: Westview Press.

Doxey, M. (1996). International Sanctions in Contemporary Perspective. Houndmills, Basingstoke: Macmillan Press.

Dündar Sezer, T. (2013). Kadınlara Karşı Ayrımcılığın Önlenmesi Komitesinin R.K.B/Türkiye Kararı ve Kararda Benimsenen Görüşlerin Olası Etkileri. AYHD, 2(4): 405-436.

Farrall, J.M. (2007). United Nations Sanctions and the Rule of Law. Cambridge: Cambridge University Press.

Forsythe, P.D. (2012). Human Rights in International Relations. Cambridge: Cambridge University Press.

Forsythe, P.D. (2016). Human Rights. A.F. Cooper, Jorge, H. ve Ramesh, T. (Der.), Oxford Handbook of Modern Diplomacy. Oxford Handbooks Online.

Freeman, R. (2013). The United Nations Human Rights Council, A Critique and Early Assessment. Oxon: Routledge. 


\section{Deniz Kızılsümer Özer}

Frowein, J.A. (2001). Sanctions and Human Rights Law. V. GowllandDebbas (Der.), United Nations Sanctions and International Law. The Hague, London, Boston: Kluver Law International.

Gülmez, M. (2004). Birleşmiş Milletler Sisteminde İnsan Haklarının Korunması. Türkiye Barolar Birliği Yayınları, 60. Ankara: Şen Matbaa.

Haas, M. (2008). International Human Rights A Comprehensive Introduction. London ve New York: Routledge.

Hehir, A. (2013). The Performance of Inconsistency, Libya, Security Council and Responsibility to Protect. International Security, 38(1).

Higgins, R. (2007). Human Rights in the Court of Justice. Leiden Journal of International Law, 20(4), 745-751.

Higgins, R. (2016). The UN at 70 Years: The Impact upon International Law. ICLQ, 65(1), 1-19.

Kızıısümer Özer, D. (2008). BM Soykırım Sözleşmesinin Uygulanmasına İlişkin Dava (Bosna Hersek v. Sırbistan). UHP, 4(15), 61-84.

Kızılsümer Özer, D. (2014). İnsan Haklarının Uluslararası Düzeyde Korunması. E. Balta (Ed.), Küresel Siyasete Giriş, Uluslararası İlişkilerde Kavramlar, Teoriler, Süreçler (ss. 356-362). İstanbul: İletişim.

Martin, F.F. vd. (2011). International Human Rights \& Humanitarian Law, Treaties, Cases, \& Analysis. Cambridge: Cambridge University Press.

Mertus, J.A. (2005). The United Nations and Human Rights, A Guide for A New Era. Routledge, London ve New York.

Schabas, W. (2010). The International Criminal Court: A Commentary on the Rome Statute. Oxford ve New York: Oxford University Press.

Schmitz, H.P. ve Sikkink, K. (2005). International Human Rights. W. Carlsnaer, T. Risse ve B.A. Simmons (Der.), Handbook of International Relations. London: Sage Publications.

Shaw, M.N. (2008). International Law. Cambridge: Cambridge University Press.

Special Research Report (2016). Human Rights and Security Council- An Evolving Role.

Steiner, H.J. (2010). International Protection of Human Rights. Malcolm, E. (Der.), International Law. Oxford: Oxford University Press.

Stewart, N.F. (2008). International Protection of Human Rights: The United Nations System. The International Journal of Human Rights, 12(1), 89-105. 
İnsan Haklarının BM'nin Kurumsal Yapısı İçinde Korunması

Sur, M. (2013). Birleşmiş Milletler Örgütünün Gelişimi ve Geleceği. Journal of Yaşar University, 8, 2535-2550.

Thakur, R. (2011). R2P, Libya, and International Politics as the Struggle for Competing Normative Architectures. e-International Relations (07.09.2011).

Thakur, R. ve Weiss, T.G. (2009). R2P: From Idea to Norm and Action? Global Responsibility to Protect, 1(1), 1-45.

Weiss, T. (2011). R2P Alive and Well after Libya. Ethics and International Affairs, 25(3), 287-292. 